\title{
KESEHATAN IBU HAMIL
}

\section{KELOMPOK 5 :}

1. Randi Surya Rannu (70200120070)

2. Juman Ahmad Taufik (70200120051)

3. Putri Nurmaeni $(70200120027)$

4. Cita Qanitah A.(70200120061) 


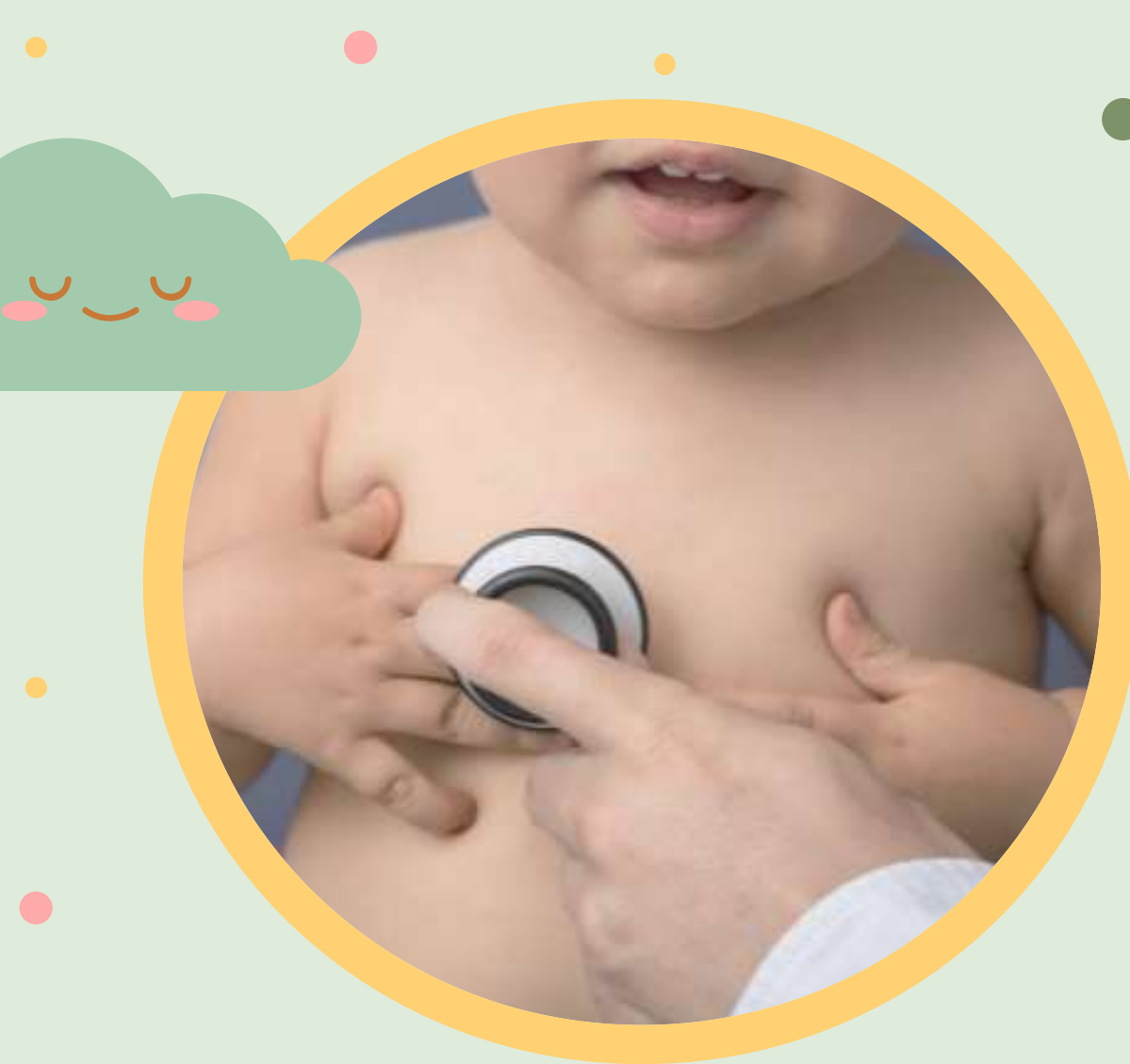

-

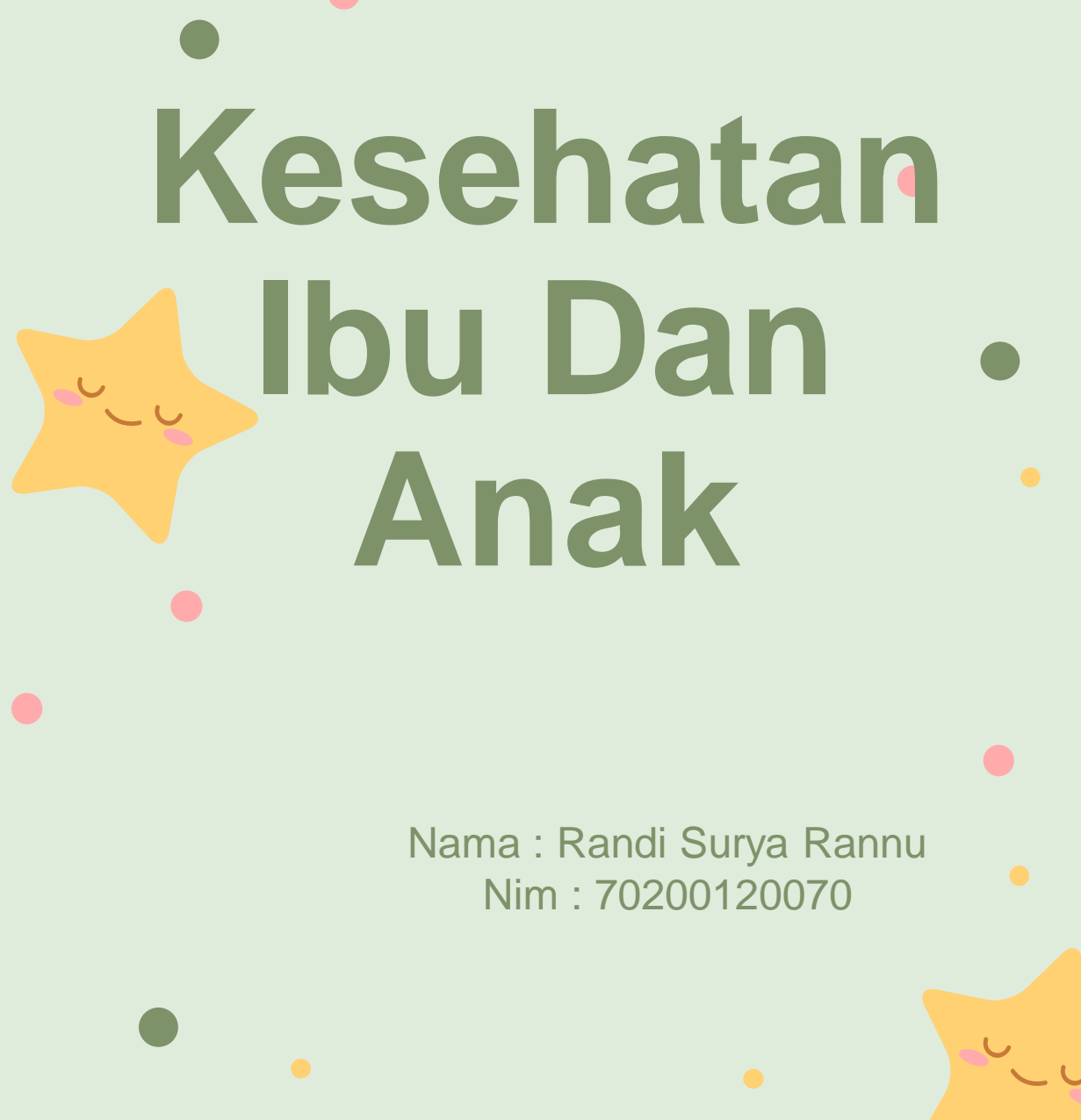


Dampak pada janin Kurang gizi pada ibu hamil dapat mempengaruhi proses pertumbuhan janin dan dapat menimbulkan keguguran, bayi lahir mati, kematian neonatal, cacat bawaan dan lahir dengan BBLR.1 Pola makan yang kurang beragam, porsi makan yang kurang dan pantangan terhadap suatu makanan merupakan factor yang berpengaruh terhadap kejadian KEK.2 Kejadian KEK dapat menunjang angka kematian Ibu di Indonesia. Status gizi ibu hamil buruk yaitu ibu hamil dengan KEK menyumbang kelahiran bayi BBLR (berat badan lahir rendah). Bayi dengan BBLR merupakan factor risiko mengalami stunting. Siklus tersebut akan selalu berputar jika tidak segera memutuskan rantai yang menghubungkan masalah tersebut. 
Faktor-faktor yang mempengaruhi status gizi ibu hamil terdapat dua faktor yaitu faktor eksternal dan faktor internal, faktor eksternal diantaranya pendapatan, pekerjaan, pendidikan dan budaya. Faktor internal terdiri dari Usia, kondisi fisik dan Infeksi.4 Hasil yang di dapatkan dalam pengabdian ini sebagian besar pekerjaan ibu hamil adalah ibu rumah tangga sebesar $(80,8 \%)$. Usia sebagian besar berada pada usia 2035 tahun maka dimungkinan karakteristik ibu hamil ini mempengaruhi pengetahuan tentâng gizi ibu hamil.

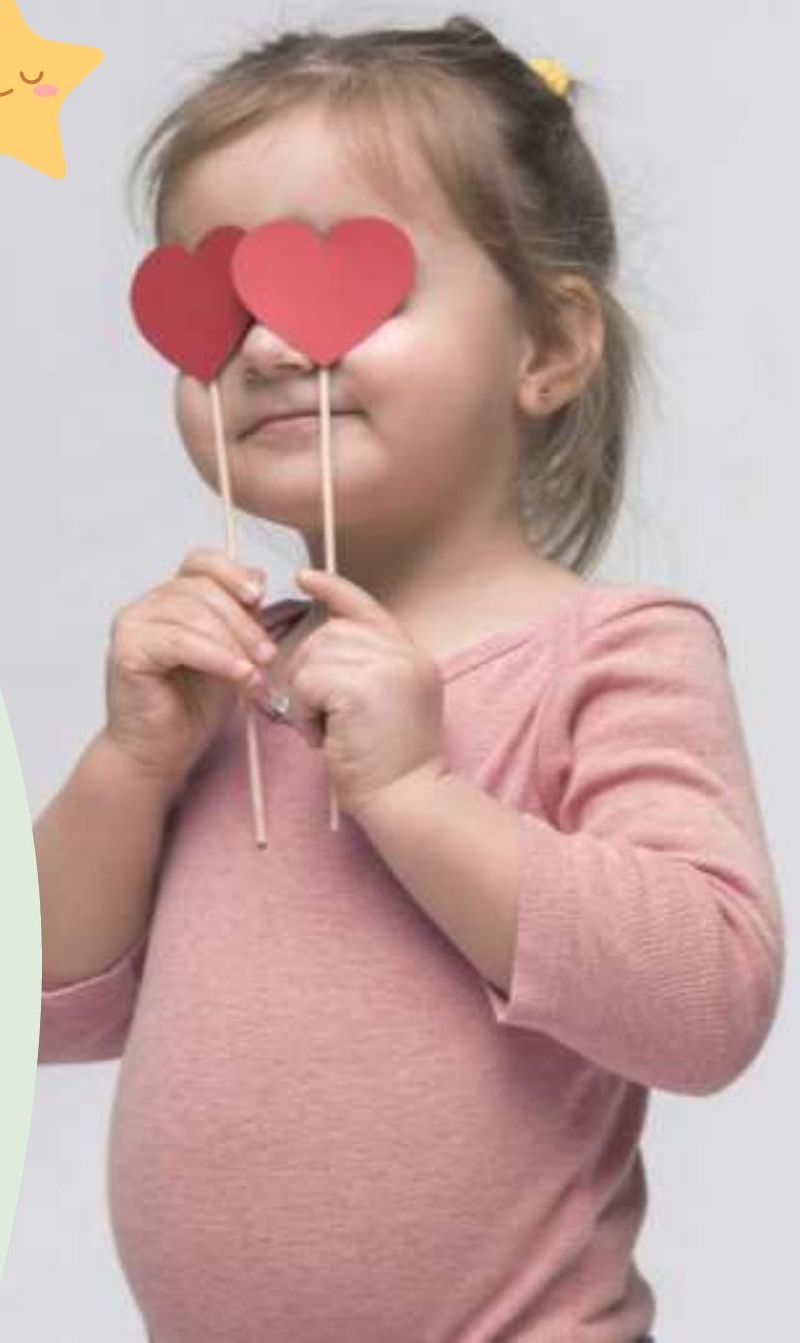




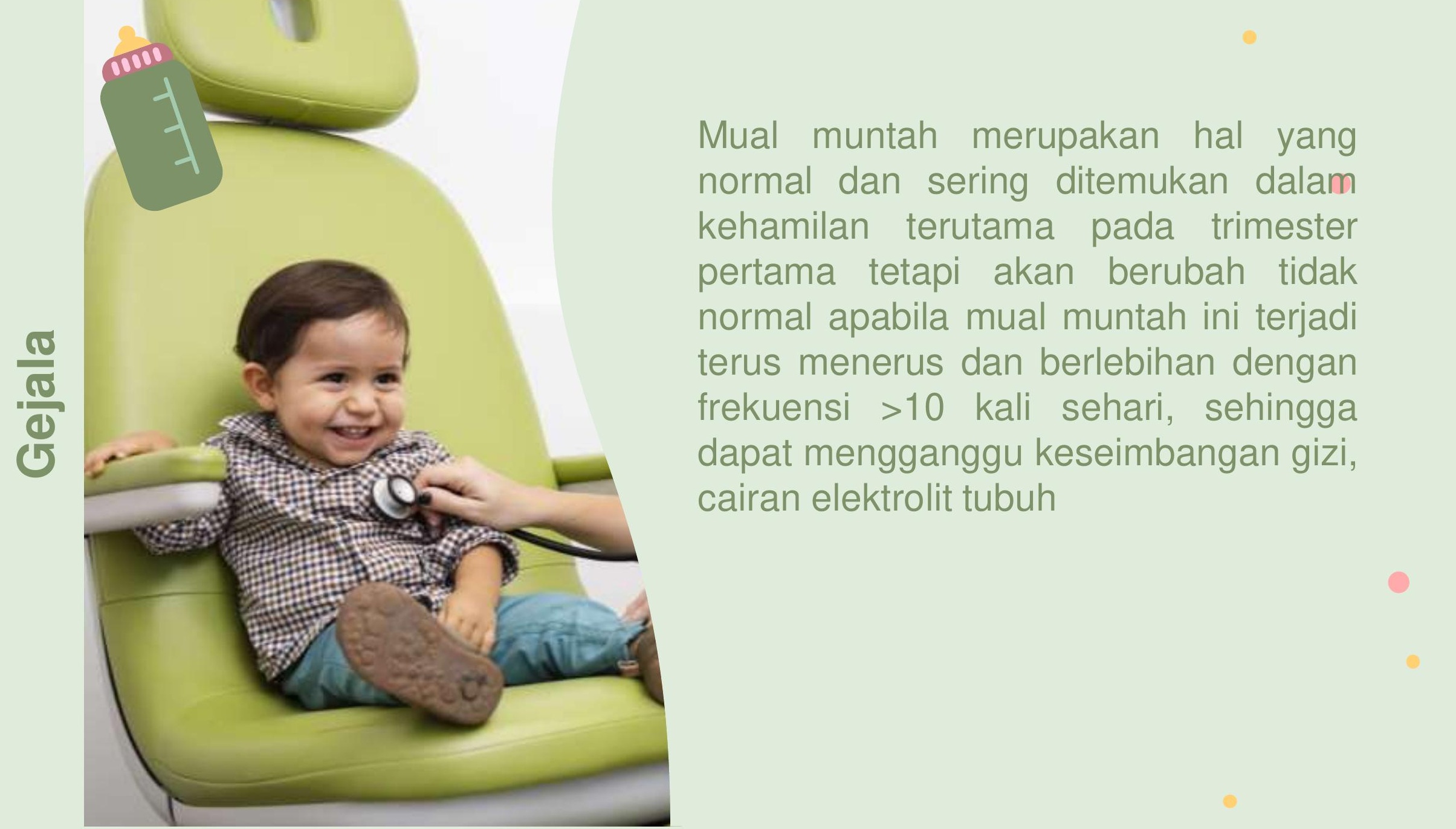


Hyperemesis Gravidarum terjadi diseluruh dunia dengan angka kejadian beragam, diseluruh kehamilan di swedia sebanyak $0,3 \%$, di California sebanyak 0,5\%, di Canada sebanyak 0,8\%, di China 0,8\%, di Norwegia sebesar 0,9\%, di Pakistan 2,2\% dan di Turki sebanyak 1,9\%. Word Health Organizatition (WHO) menyatakan jumlah kejadian hyperemesis gravidarum mencapai $12,5 \%$ dari seluruh kejadian di dunia 
Penyebab mual muntah ini bermacam-macam diantaranya adalah perubahan hormon dalam tubuh, seperti peningkatan hormon estrogen, dan dikeluarkannya Human Chorionik Gondothropine dalam serum. Pola makan yang buruk sebelum maupun seminggu awal kehamilan, kurang tidur atau kurang istrahat dan stres dapat memperberat rasa mual muntah. Beberapa hal yang dapat dilakukan untuk mengurangi rasa mual adalah misalnya dengan mengkonsumsi makanan seimbang, cukup bergerak dan cukup beristrahat. Oleh karena itu calon ibu diharapkan memiliki Cengetahuan yang cukup mengenai mual agar ibu dapat menentukan sikap untuk mengatasi masalahnya pada awal kehamilan

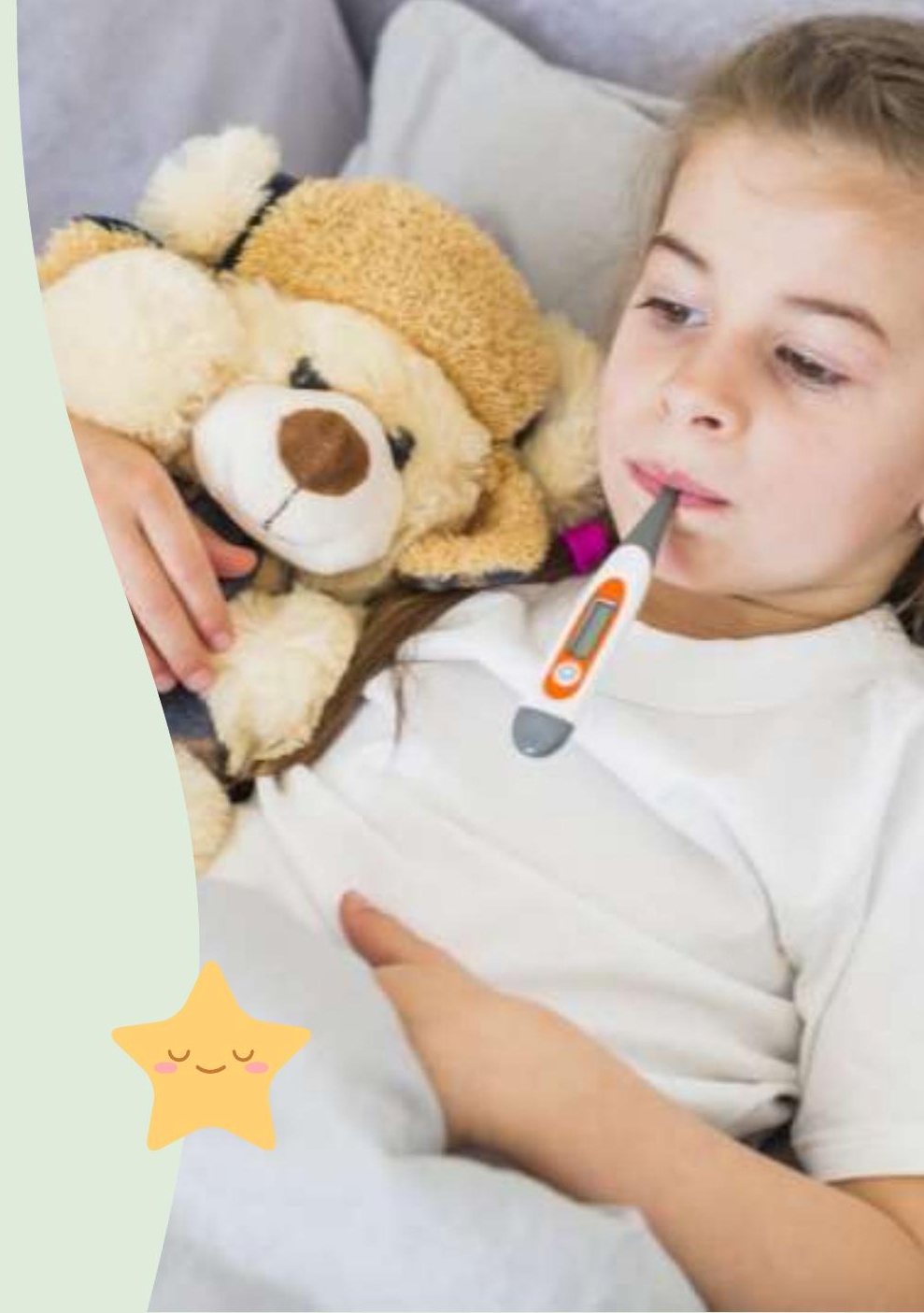


Akibat meremehkan rasa mual dan muntah yang dirasakan wanita disaat kehamilan terbukti berkontribusi dalam meningkatkan ketegangan emosional, stress psikologi dan keterlambatan yang tidak semestinya dalam menemukan penanganan yang tepat, terutama menjadi patologis 

meningkatkan pengetahuan ibu hamil tentang gizi ibu hamil, hal ini dapat diketahui dari pengukuran pengetahuan sebelum dan sesudah di berikan pendidikan kesehatan. Harapannya ibu hamil tidak berhenti disini untuk menggali informasi, informasi bisa di dapatkan dari media cetak dan media elektronik atau mengikuti pendidikan kesehatan yang selanjutnya supaya status gizi terjaga dengan baik dan mampu mengurangi resiko tinggi kehamilannya.

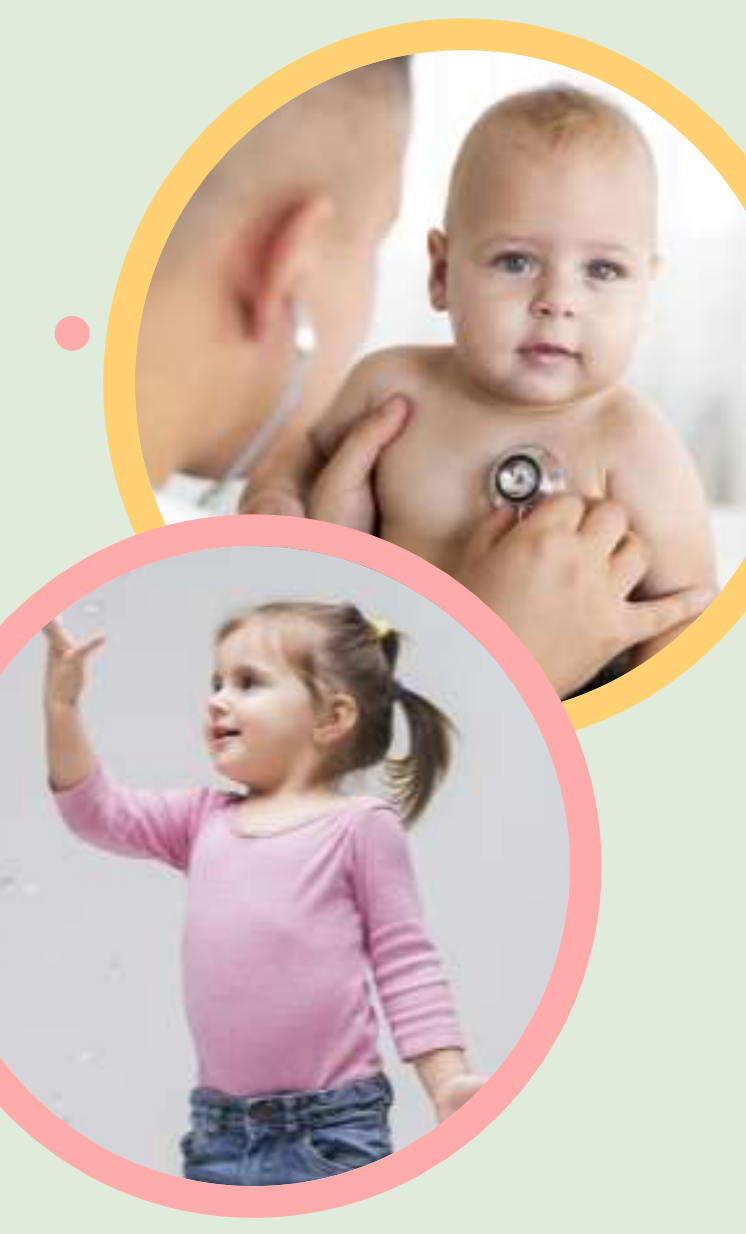




\section{Thanks!}

CREDITS: This presentation template was created by Slidesgo, including icons by Flaticon, and infographics \& images by Freepik.
○ 


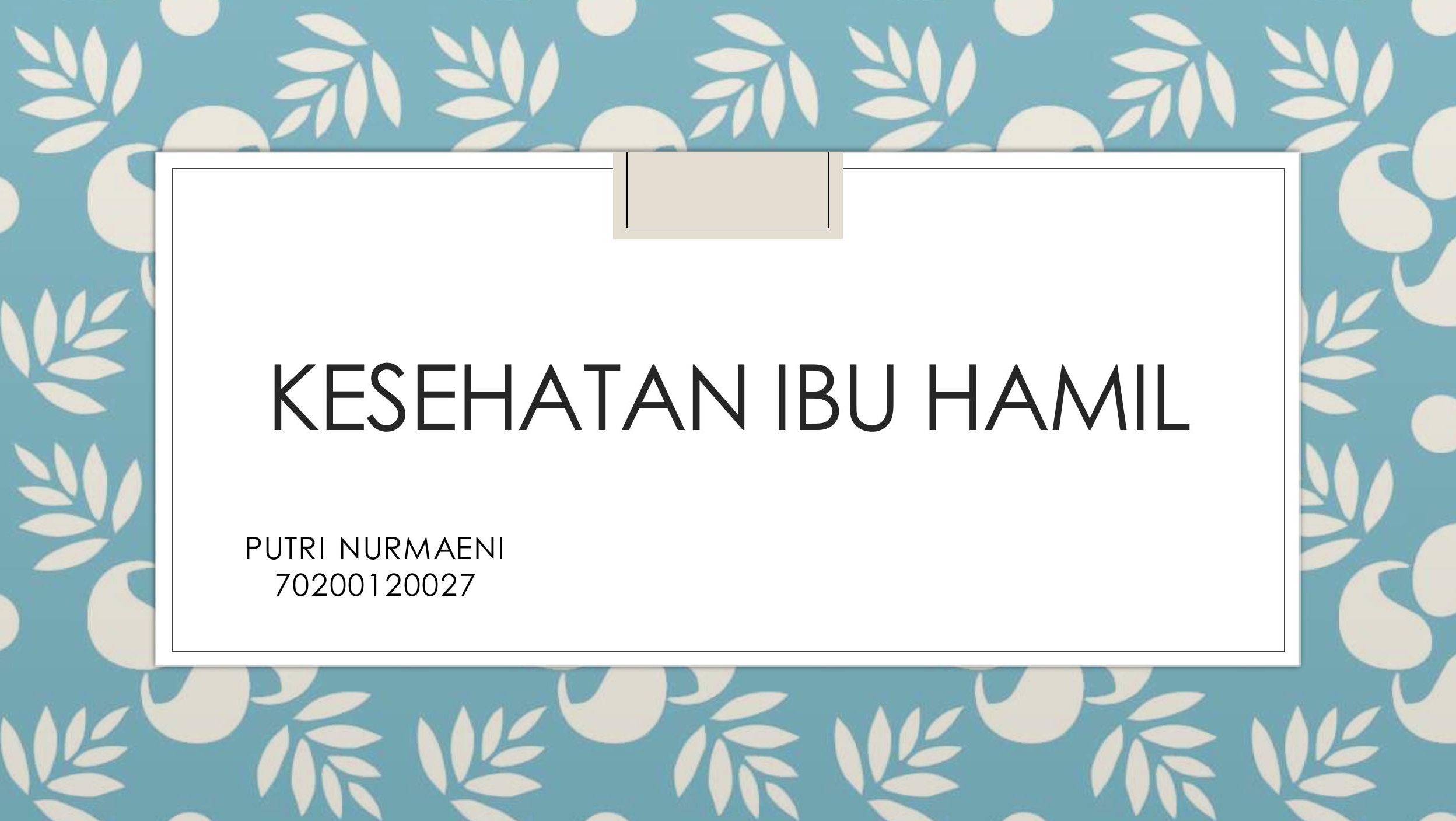




\section{Bahaya Kekurangan Gizi}

1. Pada Ibu Hamil.

Pada setiap tahap kehamilan, seorang ibu hamil membutuhkan makanan dengan kandungan zat-zat gizi yang berbeda dan disesuaikan dengan kondisitubuh dan perkembangan janin. Tambahan makanan untuk ibu hamil dapat diberikan dengan cara meningkatkan baik kualitas maupun kuantitas makanan ibu hamil sehari-hari, bisa juga dengan memberikan tambahan formula khusus untuk ibu hamil. Apabila makanan selama hamil tidak tercukupi maka dapat mengakibatkan kekurangan gizi sehingga ibu hamil mengalami gangguan. Gizi kurang pada ibu hamil dapat menyebabkan risiko dan komplikasi pada ibu hamil, antara lain anemia, berat badan tidak bertambah secara normal dan terkena infeksi.

\section{Pada janin}

Untuk pertumbuhan janin yang baik diperlukan zat-zat makanan yang adekuat, dimanan peranan plasenta besar artinya dalam transfer zat-zat makanan tersebut. Suplai zat-zat makanan kejanin yang sedang tumbuh tergantung pada jumlah darah ibu yang mengalir melalui plasenta dan zat-zat makanan yang diangkutnyaGangguan suplai makanan dari ibu mempengaruhi proses pertumbuhan janin dan dapat menimbulkan keguguran (abortus), bayi lahir mati (kematian neonatal), cacat bawaan, lahir dengan berat badan lahir rendah (BBLR) (Prawiroharjo 2008 h 65). 


\section{Faktor Penyebab Ibu Hamil Kurang Energi Kronis}

\section{Faktor Pendapatan Keluarga}

Masyarakat makin lama makin tumbuh dan kompleks. Sedikit sekali diantara kita yang menanam makan kita sendiri. Banyak makanan yang harus dibeli dari pasar. Perilaku konsumsi makan merupakan refleksi dari interaksi antara faktor ekonomi dengan faktor sosial budaya. Faktor ekonomi berhubungan dengan tingkat pendapatan dan melahirkan daya beli seseorang atau sekelompok orang apabila tingkat pendapatan tersebut seimbang dengan jumlah anggota keluarga yang menjadi bebannya.Pendapatan keluarga dalam hal ini merupakan semua penghasilan atau permintaan dari semua anggota keluarga yang diperoleh baik yang berupa upah atau gaji, dan dapat dinilai dalam Tinggi > Rp.850.000,-, Sedang = Rp.450.000,- Rp.850.000,dan Rendah < Rp.450.000,- (BPS, 2008)

2. Faktor Pendidikan lbu

Pemilihan makanan dan kebiasaan diet dipengaruhi oleh pengetahuan, sikap terhadap makanan dan praktek-praktek pengetahuan tentang numakana melandasi pemilihan makanan. 
Beberapa studi menunjukkan bahwa jika tingkat pendidikan dari ibu meningkat maka pengetahuan nutrisi dan praktik nutrisi bertambah baik. Usaha-usaha untuk memilih makanan yang bernilai nutrisi makin meningkat, ibu-ibu rumah tangga yang mempunyai pengetahuan nutrisi akan memilih makanan yang lebih bergizi dari pada yang kurang bergizi. Pendidikan ibu dalam penelitian ini di bagi dalam tingkatan dari SD, SMP, SMA/MA, dan S1 (Harahap 2002, h 48).

\section{Faktor Umur Ibu}

Melahirkan anak pada usia ibu yang muda atau terlalu tua mengakibatkan kualitas janin/anak yang rendah dan juga akan merugikan kesehatan ibu (Baliwati, 2004; h. 3). Pada ibu yang terlalu muda (kurang dari 20 tahun) dapat terjadi kompetisi makanan antara janin dan ibunya sendirii yang masih dalam masa pertumbuhan. Umur ibu dalam kehamilan yang sekarang diukur dengan umur yang $\leq 20$ tahun, 21-35 tahun, > 35 tahun (Supariasa, 2002; h. 187).

\section{Faktor Paritas}

Paritas adalah berapa kali seorang ibu telah melahirkan. Dalam hal ini ibu dikatakan terlalu banyak melahirkan adalah lebih dari 3 kali.Untuk paritas yang paling baik adalah 2 kali Jarak melahirkan yang terlalu dekat akan menyebabkan kualitas janin/anak yang rendah dan juga akan merugikan kesehatan ibu, ibu tidak memperoleh kesempatan untuk memperbaiki tubuhnya sendiri karena ibu memerlukan energi yang cukup untuk memulihkan keadaan setelah melahirkan anaknya. Berapa kali seorang ibu pernah melahirkan Bayi (parietas) diukur dalam Baik jika 2 kali, dan Buruk jika $\geq 3$ kali (Baliwati, 2004; h. 3- 6).

\section{Faktor Pola Konsumsi Makanan}

Kurang Energi Kronis merupakan keadaan dimana seseorang menderita ketidak seimbangan asupan gizi (energi dan protein) yang berlangsung menahun terutama pada wanita usia subur termasuk remaja putri. 
Upaya mencapai status gizi masyarakat yang baik atau optimal dimulai dengan penyediaan pangan yang cukup. Penyediaan pangan yang cukup diperoleh melalui produksi pangan dalam negeri yaitu upaya pertanian dalam menghasilkan bahan makanan pokok, lauk-pauk, sayursayuran, dan buah-buahan.

Jumlah pola konsumsi makanan selama 1 hari dalam makanan diukur dengan Baik jika makan dengan porsi 4 sehat 5 sempurna, Cukup jika hanya 4 sehat, dan kurang jika hanya nasi dan lauk saja (Almatsier, 2003; h.13-15).

6. Faktor Riwayat Penyakit insfeksi sebelum hamil

Riwayat Penyakit sebelum hamil dapat bertindak sebagai pemula terjadinya kurang gizi sebagai akibat menurunnya nafsu makan, adanya gangguan penyerapan dalam saluran pencernaan atau peningkatan kebutuhan zat gizi oleh adanya penyakit. Penyakit dapat memperburuk keadaan gizi dan keadaan gizi yang jelek dapat mempermudah penyakit yang umumnya terkait dengan masalah gizi antara lain diare, tuberculosis, lambung, tipes dan DM (Supariasa, 2002; h. 187). 


\section{Kesimpulan}

1. Faktor penyebab ibu hamil kurang energi kronis, dari factor pendapatan sebagian besar ibu hamil berpendapatan sedang (Rp.450.000.,- Rp.850.000.,) yang berjumlah 16 responden dengan prosentase $53,3 \%$.

2. Faktor penyebab ibu hamil kurang energi kronis, dari factor Pendidikan ibu hamil yang Kekurangan Energi Kronis (KEK) sebagian besar adalah berpendidikan SMP yaitu 12 orang dengan prosentase $40 \%$.

3. Faktor penyebab ibu hamil kurang energi kronis, dari factor Parietas ibu yang Kekurangan Energi Kronis sebagian besar adalah parietas baik (1-2 kali hamil) 23 ibu hamil prosentase 76,7\%.

4. Faktor penyebab ibu hamil kurang energi kronis, dari Umur Kekurangan Energi Kronis seblagian besar adalah umur ibu antara 21 - 35 tahun dengan jumlah 27 ibu hamil yaitu $90 \%$.

5. Faktor penyebab ibu hamil kurang energi kronis, dari Faktor Pola Konsumsi makan ibu yang Kekurangan Energi Kronis sebagian besar adalah pola konsumsi baik dengan jumlah 18 ibu hamil dan prosentase $60 \%$.

6. Faktor penyebab ibu hamil kurang energi kronis dari.Faktor penyakit sebelum hamil sebagian besar tidak memiliki penyakit sebelum hamil $86,7 \%$. 


\section{Daftar pustaka}

1. Muliawati, S. (2013). Faktor Penyebab Ibu Hamil Kurang Energi Kronis di Puskesmas Sambi Kecamatan Sambi Kabupaten Boyolali Tahun 2012. Infokes: Jurnal IImiah Rekam Medis dan Informatika Kesehatan, 3(3).

2. Prawiroharjo,S. (2008). Ilmu Kebidanan. Jakarta: PT Bina Pustaka.

3. Badan Pusat Statistik RI. 2008. Rata-rata Upah Riil Per Bulan Buruh Tahun 2008.

4. Harahap, Heryudarini. (2002). Faktor-Faktor Yang Mempengaruhi Risiko Kurang Energi Kronis (KEK) Pada Wanita Usia Subur (WUS). Bogor: Departemen Kesehatan Dan Kesejahteraan Sosial

5. Baliwati, Yayuk. (2004). Pengantar Pangan dan Gizi. Jakarta: Penebar Swadaya

6. Supariasa, I Dewa Nyoman. (2002). Penilaian Status Gizi. Jakarta: EGCVarney, Helen. (2001). Buku Saku Bidan. Jakarta: EGC

7. Almatsier, Sunita. (2001). Prinsip Dasar IImu Gizi. Jakarta: Gramedia Pustaka Utama 
TERIMA KASIH 


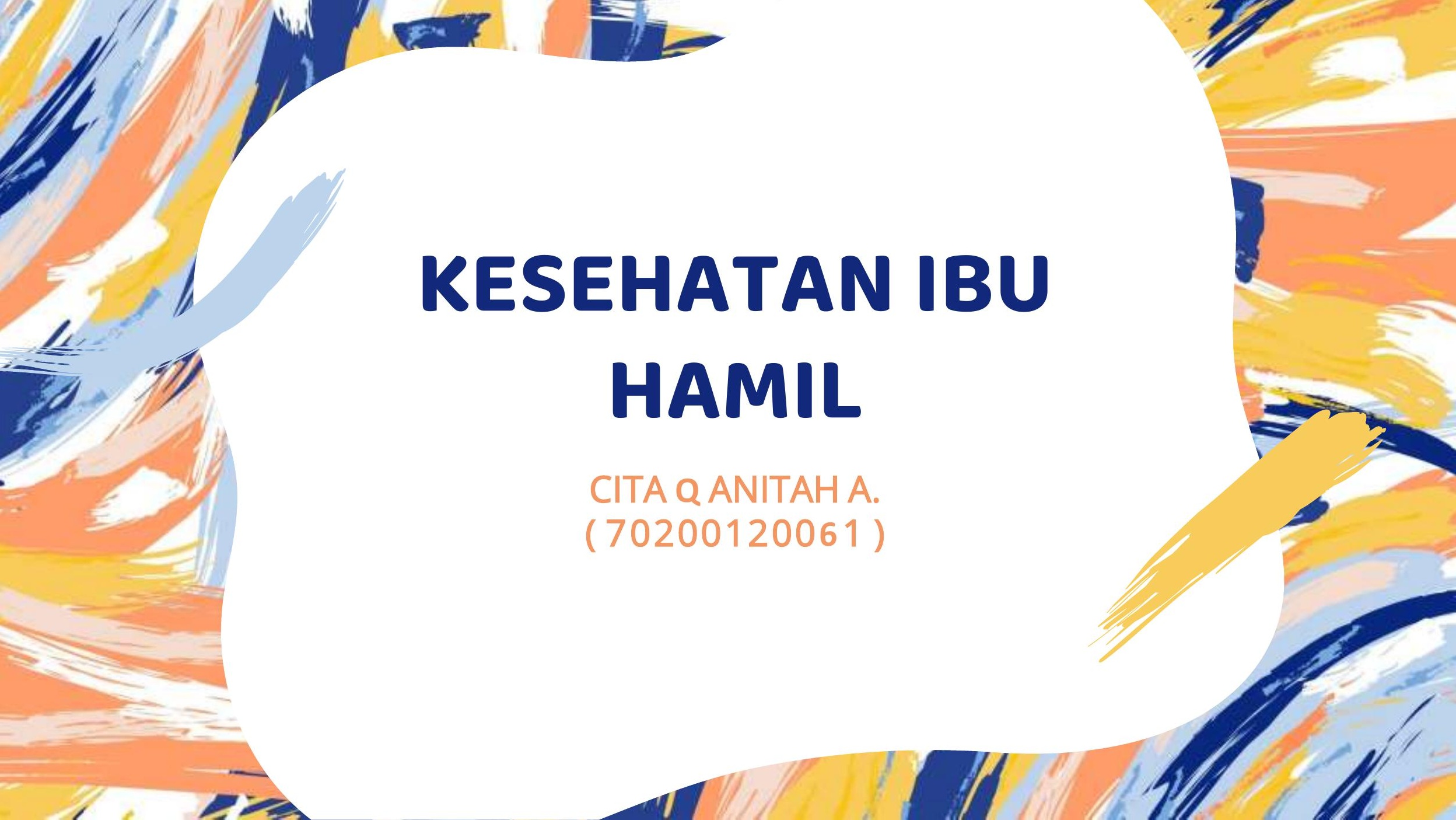


Pola makan yang buruk sebelum maupun seminggu awal kehamilan, kurang tidur atau kurang istrahat dan stres dapat memperberat rasa mual muntah. Beberapa hal yang dapat dilakukan untuk mengurangi rasa mual adalah misalnya dengan mengkonsumsi makanan seimbang, cukup bergerak dan cukup beristrahat. Oleh karena itu calon ibu diharapkan memiliki pengetahuan yang cukup mengenai mual agar ibu dapat menentukan sikap untuk mengatasi masalahnya pada awal kehamilan (Puji Nur

Hasanah, 2017). 

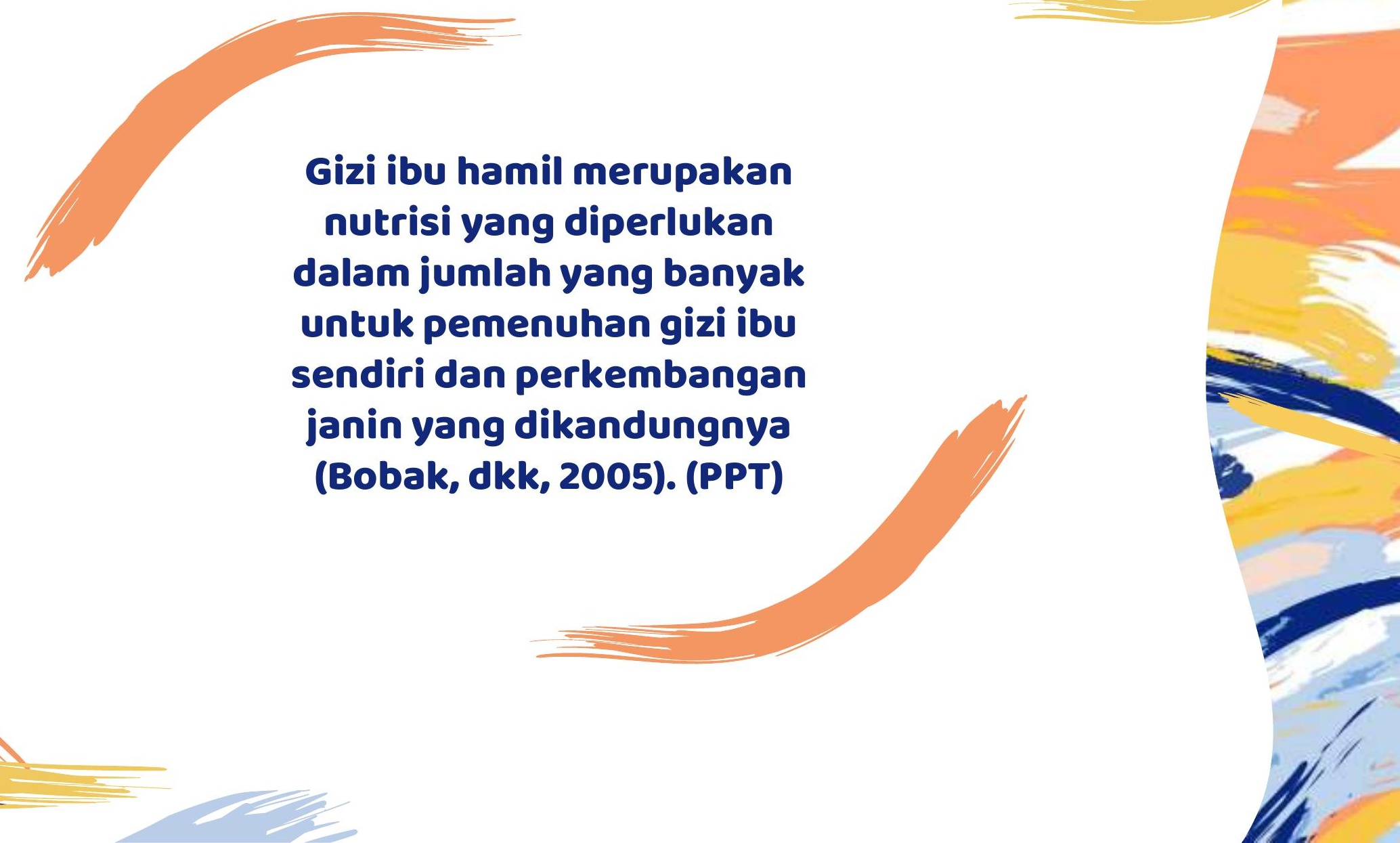


\section{Status gizi ibu hamil dipengaruhi oleh :}

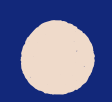

Keadaan sosial

ekonomi keadaan kesehatan

ibu hamil selama

kehamilan 


\section{Apa yang harus diperhatikan oleh Ibu Hamil ?}




\section{Beberapa hal yang perlu diperhatikan ibu hamil agar kebutuhan gizi bayi dapat terpenuhi dengan sempurna :}

1.Makan lebih banyak ( dua porsi ) dan beraneka ragam lauk pauk, sayur dan buah.

2.Tidak merokok

3.Tidak minum minuman beralkohol

4.Tidak makan mie instan sebagai makanan pokok

5.Tidak minim obat tanpa resep dokter

6.Mengikuti kelas hamil

7.Melakukan perawatan payudara untuk persiapan menyusui

8.Melakukan pemeriksaan kehamilan dan merencanakan persalinan dengan petugas kesehatan 


\section{DAFTAR PUSTAKA}

1. Ibrahim, I. A., Syahrir, S., \& Anggriati, T. Faktor-Faktor Yang Berhubungan Dengan Hyperemesis Gravidarum Pada Ibu Hamil Di RSUD Syekh Yusuf Tahun 2019. Al GIZZAI: PUBLIC HEALTH NUTRITION JOURNAL, 1(2), 59-70.

2. Ernawati, A. (2018). Hubungan Usia Dan Status Pekerjaan Ibu Dengan Kejadian Kurang Energi Kronis Pada Ibu Hamil. Jurnal Litbang: Media Informasi Penelitian, Pengembangan dan IPTEK, 14(1), 27-37.

3. Goni, A. P., Laoh, J. M., \& Pangemanan, D. H. (2013). Hubungan pengetahuan dan sikap ibu hamil dengan status gizi selama kehamilan di puskesmas Bahu kota Manado. Jurnal Keperawatan, 1(1). 


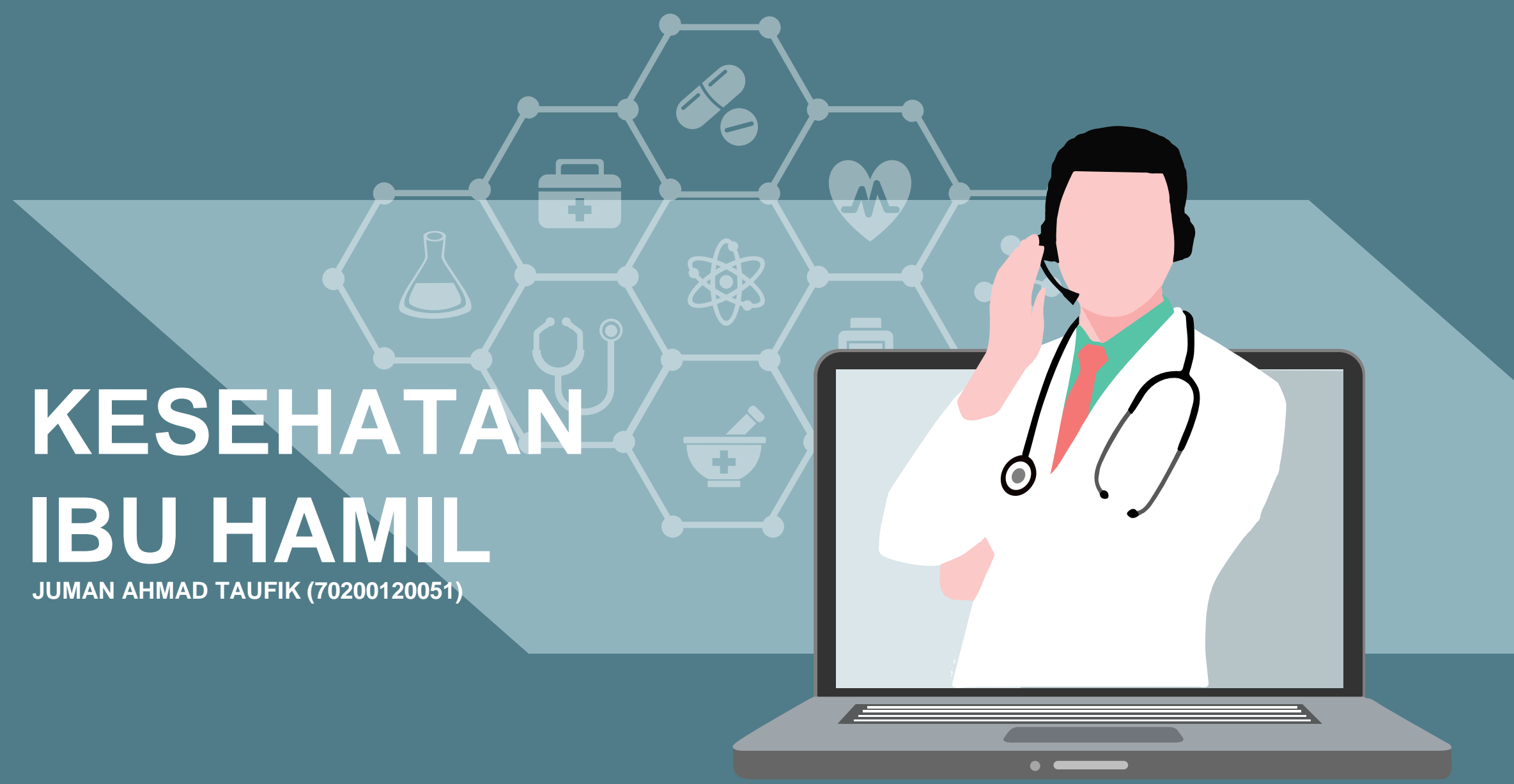


Kehamilan dan persalinan adalah suatu hal yang alami akan tetapi bukan berarti tanpa resiko, masalah kehamilan dan persalinan adalah penyumbang terbesar Angka Kematian Ibu dan Angka Kematian Bayi. Kesehatan Ibu dan Anak menjadi target dalam tujuan pembangunan millenium (MDG's), tepatnya pada tujuan 4 dan 5 yaitu menurunkan angka kematian anak dan meningkatkan kesehatan ibu. Word Health Organizatition (WHO) menyatakan bahwa perempuan mengandung selama mengandung atau melahirkan sebanyak 585.000 orang. Sedangkan kematian ibu hamil akibat kelahiran atau akibat masalah persalinan sebanyak 99\%. Rasio kematian ibu sendiri, jika dibandingkan sekitar 450 kematian ibu per 100 ribu kelahiran bayi yang hidup berada di negara- negara yang berkembang. Di Indonesia sendiri ibu hamil yang mengalami Hyperemesis Gravidarum mencapai $14,8 \%$ dan di Sulawesi Selatan mencapai $17,2 \%$ didapat dari kunjungan pemeriksa kehamilan ibu hamil (Depkes Rl, 2013). 


\section{Hal Yang Mempengaruhi Kesehatan Ibu Hamil}

\section{Pengetahuan}

Pengetahuan dapat mempengaruhi sikap dalam menghadapi komplikasi kesehatan pada saat kehamilan. Rendahnya pengetahuan seseorang makin rendah pula ibu hamil dalam menerima informasi.

\section{Sikap}

Sikap merupakan predisposisi emosional yang dipelajari untuk merespon secara konsisten terhadap suatu objek. Sikap ibu hamil dalam hal ini adalah cara ibu hamil menanggapi suatu kejadian yang akan terjadi.

\section{Dukungan Suami}

Selama kehamilan dukungan keluarga sangat dibutuhkan terutama kehadiran seorang suami. Tugas suami selain memberikan nafkah, mengingatkan waktu makan, suami juga memberikan kenyamanan dan membina hubungan baik dengan ibu hamil 


\section{Faktor Yang Berhubungan dengan Kesiapan Psikologis Ibu Hamil}

Selama kehamilan kebanyakan wanita mengalami perubahan psikologis dan emosional. Perubahan fisik dan emosional yang kompleks, memerlukan adaptasi terhadap penyesuaian pola hidup dengan proses kehamilan yang terjadi.

Faktor psikologis yang berpengaruh dalam kehamilan dapat berasal dari dalam diri ibu hamil (internal) dan dapat juga berasal dari faktor luar diri ibu hamil.Faktor prikologis yang mempengaruhi kehamilan berasal dari dalam diri ibu dapat berupa latar belakang kepribadian ibu dan pengaruh perubahan hormonal yang terjadi selama kehamilan.Faktor psikologis yang berasal dari luar diri ibu dapat berupa pengalaman lbu, kecemasan dan gangguan emosi, dukungan keluarga, dan dukungan suami. (Elvina, 2018) 


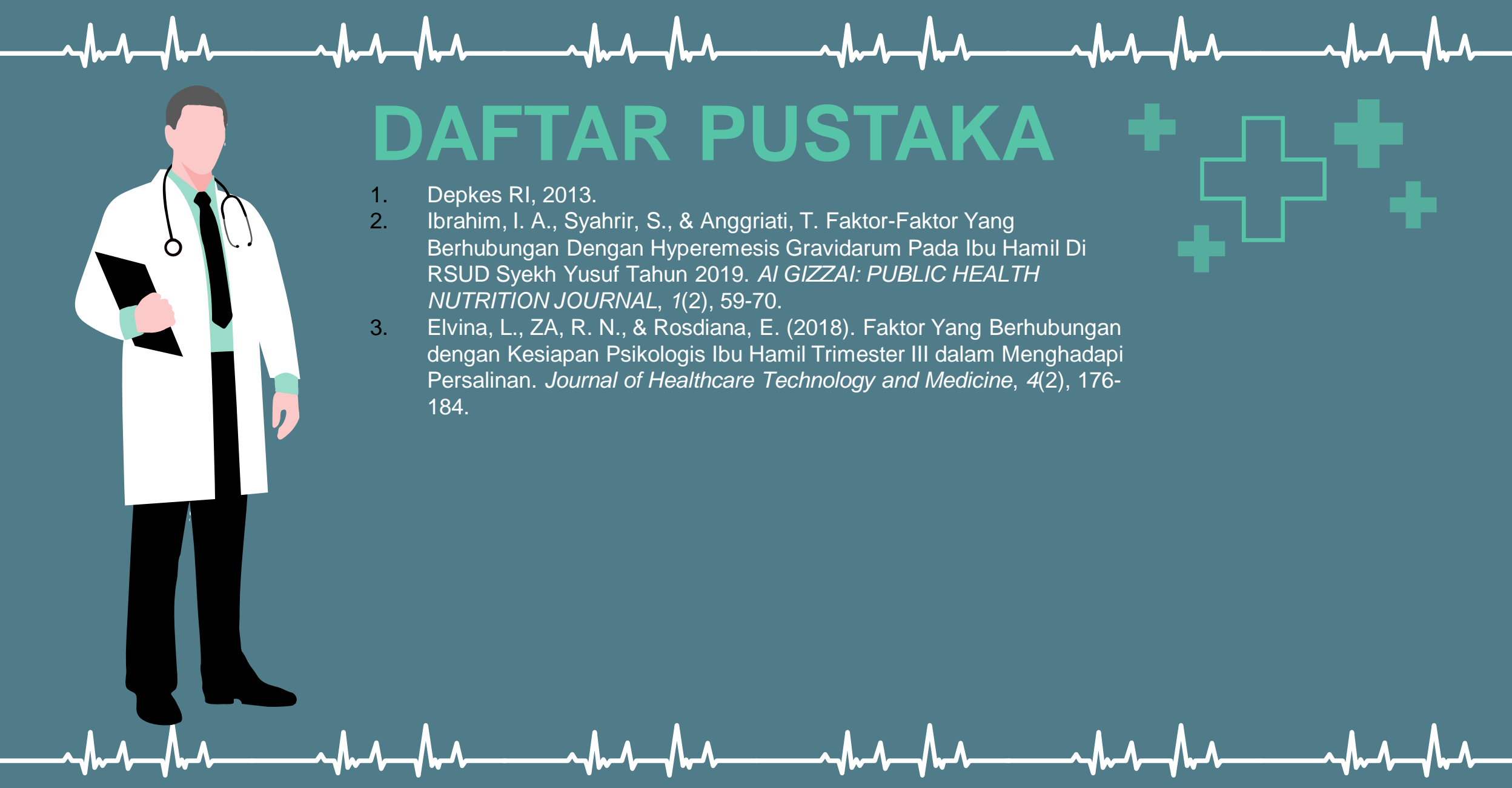




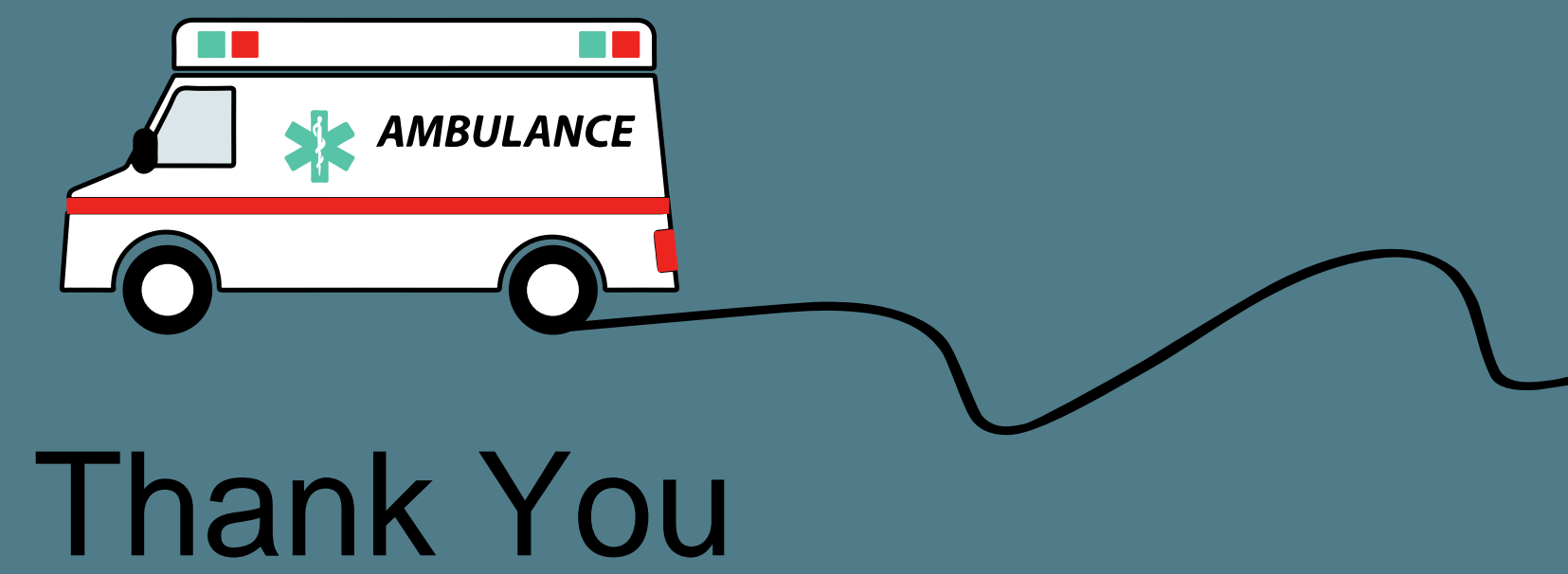

Dunia Sementara, Akhirat Selama-lamanya

en $\sim$ $\sim$ 